\title{
Analysis of cloud-to-ground lightning and its relation with surface pollutants over Taipei, Taiwan
}

\author{
S. K. Kar ${ }^{1, *}$ and Y. A. Liou ${ }^{1, *}$ \\ ${ }^{1}$ Center for Space and Remote Sensing Research, National Central University, Jhong-Li, Taiwan \\ *These authors contributed equally to this work. \\ Correspondence to: S. K. Kar (sanjib_kar@hotmail.com) and Y. A. Liou (yueian@csrsr.ncu.edu.tw) \\ Received: 6 February 2014 - Revised: 30 May 2014 - Accepted: 3 July 2014 - Published: 3 September 2014
}

\begin{abstract}
Premonsoon (March-April) cloud-to-ground (CG) lightning activity over Taipei, Taiwan, is analyzed in relation to surface pollutants like particulate matter $\left(\mathrm{PM}_{10}\right)$, sulfur dioxide $\left(\mathrm{SO}_{2}\right)$, nitrogen oxides $\left(\mathrm{NO}_{\mathrm{x}}\right)$ and ozone $\left(\mathrm{O}_{3}\right)$ concentration for a period of 6 years (2005-2010). Other surface parameters like aerosol optical depth and cloud top temperature are also investigated taking data from Moderate Resolution Imaging Spectroradiometer satellite products. Results reveal that $\mathrm{SO}_{2}$ is more strongly associated with CG lightning activity compared to $\mathrm{PM}_{10}$ concentration. Other surface pollutants like $\mathrm{NO}_{\mathrm{x}}$ and $\mathrm{O}_{3}$ also show strong linear association with CG lightning flashes. Additional investigations have also been performed to extreme lightning events, particularly to a few long-lasting lightning episodes considering the concentrations of $\mathrm{NO}_{\mathrm{x}}$ and $\mathrm{O}_{3}$ found on days with no lightning activity as representative of the background concentration levels of the said two parameters. Results indicate that the $\mathrm{NO}_{\mathrm{x}}$ concentration on days with lightning activity is more than 2-fold compared to the non-lightning days while the $\mathrm{O}_{3}$ concentration is increased by 1.5 -fold. Such increase in $\mathrm{NO}_{\mathrm{x}}$ and $\mathrm{O}_{3}$ concentration on days with lightning strongly supports the transport phenomena of $\mathrm{NO}_{\mathrm{x}}$ and $\mathrm{O}_{3}$ from the upper or middle troposphere to the lower troposphere by downdraft of the thunderstorm during its dissipation stage. Overall, studies suggest that enhanced surface pollution in a near-storm environment is strongly related to the increased lightning activity, which in turn increases the surface $\mathrm{NO}_{\mathrm{x}}$ level and surface $\mathrm{O}_{3}$ concentration over the area under study.
\end{abstract}

Keywords. Atmospheric composition and structure (pollution - urban and regional)

\section{Introduction}

Lightning plays a crucial role in determining the regional air chemistry. Westcott (1995) first indicated the urban effect on the enhancement of cloud-to-ground (CG) lightning over cities. Since then, considerable research work has been carried out to explore the effect of an urban area on the initiation and enhancements of CG lightning (Lyons et al., 1998; Orville et al., 2001; Soriano and Pablo, 2002; Pinto et al., 2004; Farias et al., 2009; Lal and Pawar, 2011; Pawar et al., 2012a). Several studies have indicated the direct and indirect effect of pollution on our global atmosphere. Li et al. (2011) pointed out the effect of aerosol in cloud formation process and rainfall, whereas Trenberth et al. (2000) indicated how aerosol can effectively modify our weather system. Westcott (1995) suggested the possible influence of high $\mathrm{PM}_{10}$ and $\mathrm{SO}_{2}$ concentrations on the enhancement of urban $\mathrm{CG}$ lightning activity. Orville et al. (2001) reported an association of urban heat island and anthropogenic pollution in the enhancement of the flash density over and downwind of the urban area after conducting a long-term analysis over the city of Houston. Soriano and Pablo (2002) reported a possible contribution of $\mathrm{SO}_{2}$ to the increased lightning activity but did not find any significant correlation between $\mathrm{PM}_{10}$ concentration and lightning flashes in central Spain. On the other hand, Naccarato et al. (2003) reported a positive correlation between $\mathrm{PM}_{10}$ concentration and CG lightning over southern Brazil. Similar reports are also found in the literature indicating a possible relationship between $\mathrm{CG}$ lightning and both $\mathrm{PM}_{10}$ and $\mathrm{SO}_{2}$ concentration (Kar et al., 2009). Atmospheric pollutants play a crucial role in the various development stages and formation of local weather system. It is not yet well understood how the atmospheric pollutant varies 
with different phases of prevailing weather and affects the local weather conditions. It is highly essential to know the interconnectivity between various meteorological parameters and pollutant particles to study of pollution meteorology over a particular region for a specified period of time. In general, the urban heat island circulation and the possible role for air pollution have been indicated as the prime influencing factor behind such enhancement in most of these studies. From earlier studies it has been found that urban effect on local weather is apparently due to a joint action of a thermodynamic effect due to the differential heating of the city surface and an increased aerosol concentration in the local atmosphere caused mainly by human activities (Farias et al., 2009; Lal and Pawar, 2011). However, the physical mechanisms responsible for these effects are not fully understood due to the complex correlations. In recent years, meteorologists have shown much interest in exploring the physical relationship between lightning and pollution over the globe.

The influence of atmospheric pollutants on cloud systems directly affects radiation budget and indirectly affects the cloud dynamics and microphysical properties (Tie et al., 2003; Khain et al., 2005; Wang et al., 2011). Weather and climate modification by atmospheric pollutants has been indicated by Hobbs et al. (1974). Bréon et al. (2002) reported the significant consequence of aerosols on cloud microphysics on a global scale. Positive correlations between CG lightning flash density and rainfall amount have been estimated by Petersen and Rutledge (1998). Change in cloud microphysical processes leads to a change in concentration, phase, and the size of cloud particles, which in turn affects the charge separation processes in thunderclouds. Orville et al. (2001) suggested that the enhanced pollution plays a crucial role in holding back the mean droplet size in the boundary layer; as a result more cloud water would therefore be active in differentiating the electric charge, causing more CG lightning flashes. A recent study conducted by Farias et al. (2014) suggests that urban pollution tends to saturate the intensification of storms and lightning activity at a specific level.

Moreover, the chemical reactions which determine the concentrations of ozone $\left(\mathrm{O}_{3}\right)$ and hydroxyl radical $(\mathrm{OH})$ in the troposphere and stratosphere are facilitated by electric discharge-produced nitric oxide (NO) molecule. Seasonal and geographical variation of lightning-produced $\mathrm{NO}_{\mathrm{x}}$ has been compared to other $\mathrm{NO}_{\mathrm{x}}$ sources like anthropogenic activity, soil emissions and biomass burning by Bond et al. (2002) and indicated that the lightning-produced $\mathrm{NO}_{\mathrm{x}}$ remains significant throughout the year. Lightning and aircraft exhaust subscribe to ambient NO levels in the troposphere. Modified tropospheric NO levels then can either enhance or reduce the $\mathrm{O}_{3}$ levels in accordance with the local conditions and $\mathrm{NO}_{\mathrm{x}}$ level $\left(\mathrm{NO}_{\mathrm{x}}=\mathrm{NO}+\mathrm{NO}_{2}\right)$. Lightning channels primarily produce $\mathrm{NO}$ as a trace gas with less $\mathrm{NO}_{2}$. Once $\mathrm{NO}$ is produced in the atmosphere, it is always oxidized and accompanied by $\mathrm{NO}_{2}$. $\mathrm{NO}_{2}$ is dissociated into $\mathrm{NO}$ and $\mathrm{O}$ in the presence of sunlight. Successive chemical reaction and the photolyzation of $\mathrm{NO}_{2}$ maintain a balance between $\mathrm{NO}_{2}$ and NO. It has already been established that lightning-produced NO can play a crucial role in the chemistry of the earth's atmosphere, particularly, in adjusting the concentrations of $\mathrm{O}_{3}$ and $\mathrm{OH}$ (Crutzen, 1973; Chameides and Walker, 1973). Noxon (1976) first reported the enhanced concentration of $\mathrm{NO}$ in the vicinity of lightning flashes. He also reported an increase of about 2 orders of magnitude in $\mathrm{NO}_{2}$ concentration above ambient levels and as high as $100 \mathrm{ppbv}$ (parts per billion by volume). Thereafter many reports are found in the literature advocating that lightning can produce significant increases in $\mathrm{NO}_{\mathrm{x}}$ concentration in the troposphere and contribute notably to columnar abundance of $\mathrm{NO}_{2}$ (Choi et al., 2005; Martin et al., 2006).

However, $\mathrm{PM}_{10}, \mathrm{SO}_{2}, \mathrm{NO}_{\mathrm{x}}$ and $\mathrm{O}_{3}$ production due to lightning activity over Taiwan has not yet been studied extensively. The present study has been conducted considering the data of surface $\mathrm{PM}_{10}, \mathrm{SO}_{2}, \mathrm{NO}_{\mathrm{x}}$ and $\mathrm{O}_{3}$ on lightning flashes during the premonsoon season. The rainfall-lightning relationship is found more consistent during premonsoon season than monsoon season as reported by Lal and Pawar (2009). A higher ratio of premonsoon lightning flash density to rain rate is reported over the Tibet Plateau than that during monsoon season by Qie et al. (2004). Higher mean cell-level flash rate during the premonsoon season than during the monsoon season has been established by Yuan and Qie (2008). Hence, the premonsoon period has been selected for the present study. Main objective of the present study is to investigate the effect of lower tropospheric air pollutants on CG lightning activity along with other meteorological parameters over Taipei. Further investigation has also been carried out to unveil the association of CG lightning flash in surface ozone production over Taipei during premonsoon (March-April) months.

\section{Data and methodology}

Cloud-to-ground lightning data were collected from Tai Power Company of Taiwan for the period 2005-2010. The lightning location system (LLS) of Tai Power Company was built in 1989. The LLS was upgraded to a total lightning detection system (TLDS) in 2002. The TLDS consists of seven lightning detection sensors (SAFIR 3000), which are located at the top of Ying-Tsu-Ling microwave tower, WuShihpi microwave tower, Ji-Shan microwave tower, Nan-Ke extra voltage substation, Feng-Lin microwave tower, building roof of Ming-Tan power plant, and building roof of XiaoLiou-Chiou. The location of these seven sensors, distributed throughout Taiwan, is shown in Fig. 1. Very high frequency interferometric technique is the main basis for the localization principles of SAFIR network (Richard, 1985; Richard et al., 1986). The seven lightning detection sensors, forming a lightning detection network, could detect cloud-to-ground lightning discharges, cloud lightning discharges, and breakdown events. The long-range localization of all lightning 


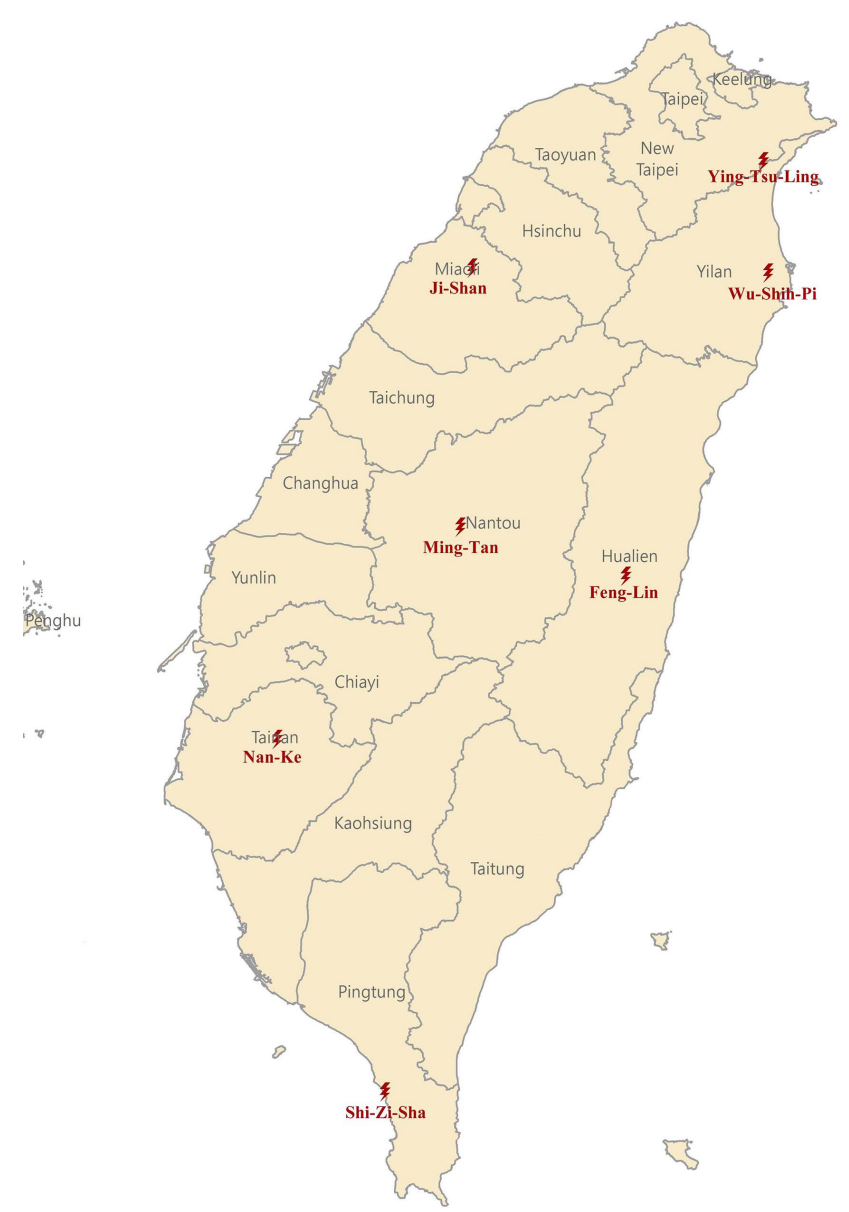

Figure 1. Map of Taiwan showing the location of the sensors and the urban area of Taipei County.

discharges ( $\mathrm{CG}$ and $\mathrm{CC}$ lightning flashes) is governed by triangulation performed on GPS time synchronized direction of arrival provided by interferometric sensor of two different detection stations in the SAFIR network. The lightning detection network average efficiency is greater than $90 \%$, and the lightning detection localization accuracy is less than $1 \mathrm{~km}$. However, especially near the edges of the network the assumption of more than $90 \%$ uniform flash detection efficiency may not be realistic.

Heights of convective condensation level (CCL) were calculated using radiosonde/rawinsonde data downloaded from the University of Wyoming website. Air pollutants data were collected from a well-organized air-quality-monitoring network operated by Taiwan Environmental Protection Administration. Taiwan's air quality monitoring network measures $\mathrm{PM}_{10}$ concentrations by the automatic Wedding $\beta$-gauge monitors, which is one of the US EPA-designated equivalent methods (no. EQPM-0391-081). The $\mathrm{PM}_{10}$ inlet is a cyclone operated at $18.9 \mathrm{~L} \mathrm{~min}^{-1}$. Particles are detected once every hour from its continuous collection on the filter tape, and the daily average is computed for at least 16 effective hours each

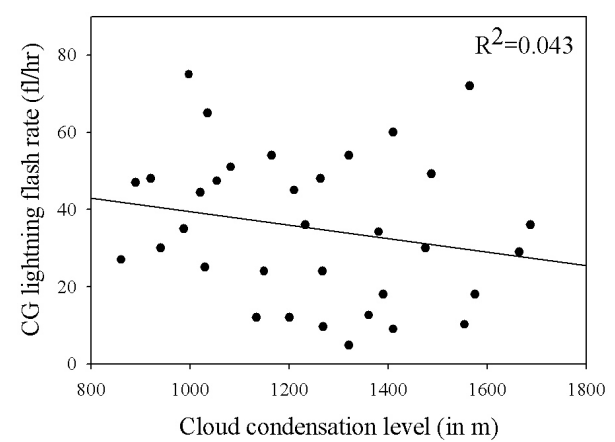

Figure 2. Scatterplot of the CG lightning flash rate and convective condensation level over Taipei during premonsoon season.

day. Seinfeld and Pandis (1998) indicated that water or moisture may be absorbed by the particles collected on the filter tape when the deliquescence point is exceeded, which may lead to an overestimation of $\mathrm{PM}_{10}$ concentration measurements. EPA of Taiwan performed a comparison experiment with Wedding $\beta$-gauge monitors and the manual samplers because of the frequent abundance of high humidity in the ambient air of Taiwan. Their results reveal that $\mathrm{PM}_{10}$ concentrations from automatic Wedding $\beta$-gauge monitor are very close to those from the manual samplers (Chang et al., 2001). For the present study $\mathrm{PM}_{10}, \mathrm{SO}_{2}$, nitrogen oxides $\left(\mathrm{NO}_{\mathrm{x}}\right)$, and ozone $\left(\mathrm{O}_{3}\right)$ over Taipei are considered. Aerosol optical depth (AOD) data are collected from the Moderate Resolution Imaging Spectroradiometer (Aqua/Terra) satellite products.

\section{Results and discussion}

Convective condensation level (CCL) is assumed as the cloud base theoretically, and its variation represents various cloud dynamics (Chaudhuri and Middey, 2011; Middey and Chaudhuri, 2013). Figure 2 represents the scatterplot of the CG lightning flash rate and CCL. It shows a negative linear correlation between the plotted parameters. This result is consistent with the physical laws that when the CCL value is low, cloud formation occurs very near to the ground and the prevailing winds helps the surface pollutants to be injected into the cloud very easily. However, from Fig. 2 it is evident that CG lightning flash rate is not influenced by high or low CCL values. On the other hand, high lightning flash rates are found irrespective of CCL heights when the high concentration of surface pollutants is available over the surface. Figure 3 represents the scatterplot of the CG lightning flash rate and SPM (suspended particulate matter). A positive correlation is evident between the plotted parameters. It is seen from Fig. 3 that the values of SPM mainly concentrated around $40-120 \mu \mathrm{g} \mathrm{m}^{-3}$, but as its value increases, the CG lightning flash count also increases. This observation can be explained from cloud microphysics. The air over Taipei 


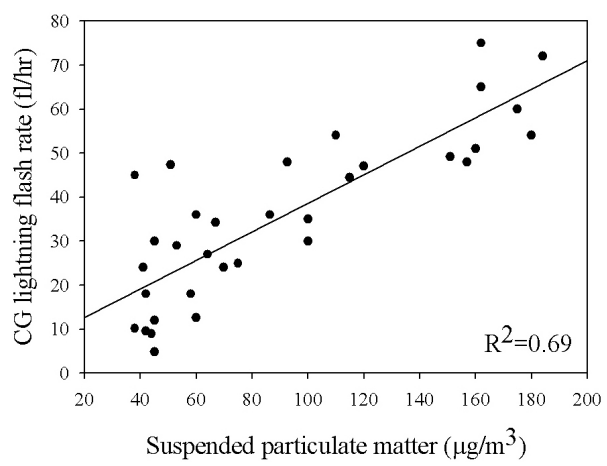

Figure 3. Scatterplot of the lightning flash rate and SPM over Taipei during premonsoon season.

is expected to be more polluted than the maritime air and hence contains a higher cloud condensation nucleus $(\mathrm{CCN})$ concentration. For such differences in boundary layer aerosol concentration, the higher $\mathrm{CCN}$ concentrations over Taipei reduce the mean cloud droplet size which in turn decreases the process of coalescence and the droplet collision efficiency (Rogers and Yau, 1989). Therefore, more supercooled water is expected to exist at greater depths in clouds. The abundance of supercooled water may produce large graupel which in turn may enhance the lightning activity over the region concerned (Williams et al., 2005; Liou and Kar, 2010). The mean annual variation of the number of CG lightning flashes during premonsoon months are plotted with annual average particulate matter $\left(\mathrm{PM}_{10}\right)$, sulfur dioxide $\left(\mathrm{SO}_{2}\right)$, nitrogen oxides $\left(\mathrm{NO}_{\mathrm{x}}\right)$, surface ozone $\left(\mathrm{O}_{3}\right)$ concentrations for the whole studied period (2005 to 2010) in Fig. 4a-d. It is worth mentioning in this context that the examination of $\mathrm{PM}_{2.5}$ along with $\mathrm{PM}_{10}$ would have been better, since the fine particles are more likely to stabilize clouds. But $\mathrm{PM}_{2.5}$ is generally not measured routinely for all the stations under study, and so high concentration episodes occurring between measurements would not be reflected in the average, possibly leading to some exposure misclassification. Therefore we have restricted our analysis to only within $\mathrm{PM}_{10}$. On an average almost similar trends of variations are observed for all the four air pollutant parameters with mean annual CG flash count over the years. The upward increase in the concentration of the atmospheric pollutants, reaching a relative maximum, with the maxima of CG lightning flash is clearly depicted. On and off, a fluctuating trend is also visible particularly in the $\mathrm{PM}_{10}$ concentrations which may be attributed to the effect of precipitation, which occurs usually now and then with atmospheric electrical activity. Such an effect is generally connected with the general precipitation washing effect of the atmosphere.

Figure 5a-d represent the scatterplot of $\mathrm{PM}_{10}, \mathrm{SO}_{2}, \mathrm{NO}_{\mathrm{x}}$ and $\mathrm{O}_{3}$ concentrations versus $\mathrm{CG}$ lightning flash count. The result of the scatterplot $5 \mathrm{a}$ and $\mathrm{b}$ suggests that $\mathrm{SO}_{2}$ concentrations are better correlated with CG lightning flash count
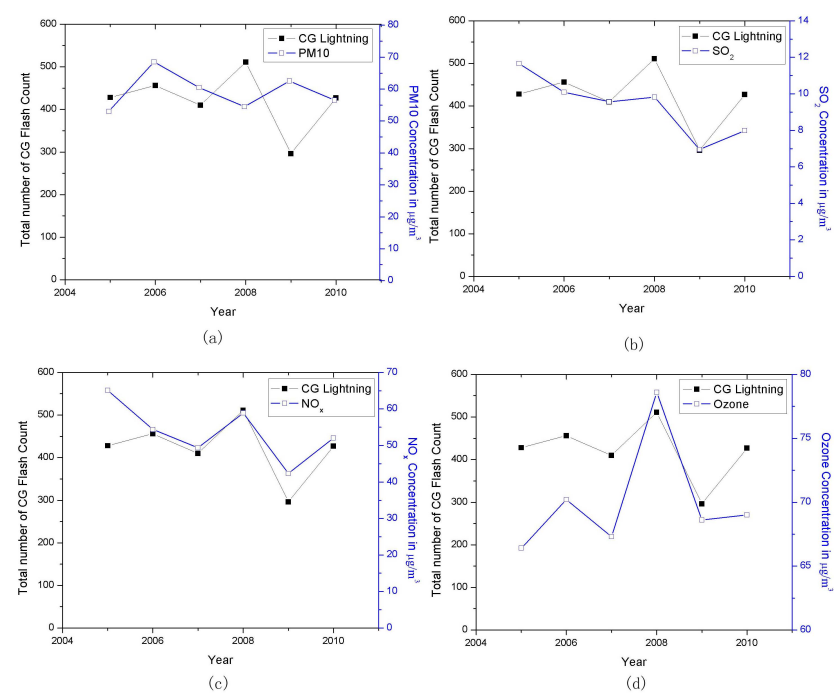

Figure 4. The mean annual variation of the number of CG lightning flashes with annual average particulate matter $\left(\mathrm{PM}_{10}\right)$, sulfur dioxide $\left(\mathrm{SO}_{2}\right)$, nitrogen oxides $\left(\mathrm{NO}_{\mathrm{x}}\right)$, surface ozone $\left(\mathrm{O}_{3}\right)$ concentrations during premonsoon months for the whole studied period (2005 to 2010).

than $\mathrm{PM}_{10}$ concentrations. Since the sulfate particles are generally more active than $\mathrm{PM}_{10}$ in the formation of cloud droplets (Seinfeld, 1975), a comparatively higher contribution from $\mathrm{SO}_{2}$ concentration is expected with $\mathrm{CG}$ lightning flashes. Hence our results corroborate well the results of Westcott (1995), who found that large annual values of $\mathrm{SO}_{2}$ and $\mathrm{PM}_{10}$ correspond generally to the large values of urban and downwind CG flashes. However, Lal and Pawar (2011) have not found any aerosol effect on lightning activity particularly over coastal cities while they have found the aerosol effect over inland stations. Very recently, Farias et al. (2014) conducted a long-term study of aerosol effect on the weekly cycles in lightning activity over São Paulo and reported that pollution tends to saturate the intensification of storm and lightning activity in a specific level. Figure $5 \mathrm{c}$ indicates a positive correlation between CG lightning flash count and $\mathrm{NO}_{\mathrm{x}}$ concentration. It is also seen from Fig. $5 \mathrm{c}$ that the $\mathrm{NO}_{\mathrm{x}}$ concentrations belong to the higher levels $\left(65 \mu \mathrm{g} \mathrm{m}^{-3}\right)$ during premonsoon lightning activity over Taipei. Such high concentration of $\mathrm{NO}_{\mathrm{x}}$ (Zhoua et al., 2005) may not be considered as a predecessor for lightning. Rather, it could be considered as the $\mathrm{NO}_{\mathrm{x}}$ production in the lower troposphere as a result of combustion due to lightning flash. Therefore, as the lightning flash count increases, $\mathrm{NO}_{\mathrm{x}}$ concentrations also show higher values. From Fig. $5 \mathrm{~d}$ a positive linear correlation is again found between CG lightning flash count and nearsurface ozone concentration over Taipei. It is worth mentioning in this context that lightning-induced $\mathrm{NO}_{\mathrm{x}}$ is not the only source of tropospheric $\mathrm{NO}_{\mathrm{x}}$ but other sources like biomass burning, fossil fuel combustion, oxidation of atmospheric ammonia, soil release, and penetration of stratospheric $\mathrm{NO}_{\mathrm{x}}$ 


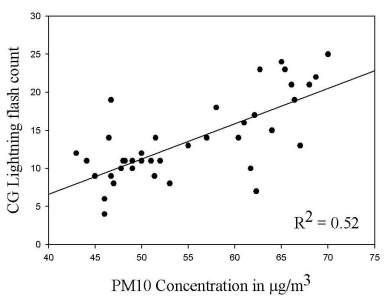

(a)

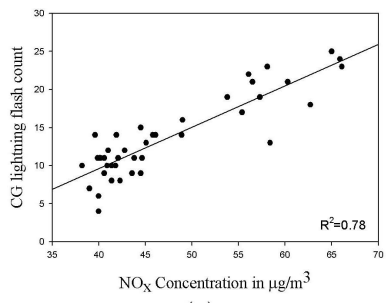

(c)

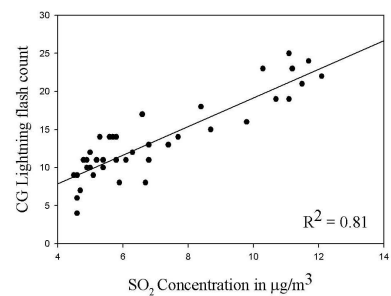

(b)

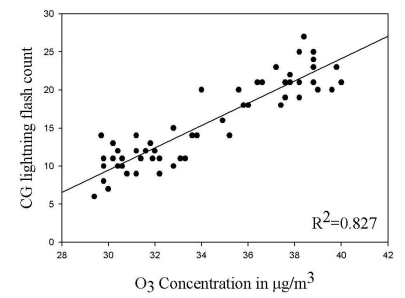

(d)
Figure 5. Scatterplot of $\mathrm{PM}_{10}, \mathrm{SO}_{2}, \mathrm{NO}_{\mathrm{x}}$ and $\mathrm{O}_{3}$ concentrations versus CG lightning flash count during premonsoon months for the whole studied period (2005 to 2010).

contribute to the tropospheric $\mathrm{NO}_{\mathrm{x}}$ as well. From the present research report it seems that premonsoon CG lightning has a significant contribution in $\mathrm{NO}_{\mathrm{x}}$ production over the city of Taipei. It has been reported that during the warm season the southwesterly flow, enriched with abundant moisture, is potentially unstable and brings warm, moist air from the South China Sea to Taiwan (Chen and Chen, 2003). This unstable, warm, moist air from the west coast then moves towards the land and meets the central mountain ridge (CMR), where orographic lifting is expected to take place. Besides orographic lifting, orographic blocking (Li et al., 1997; Yeh and Chen, 2002) and thermally driven circulations during the diurnal heating cycle (Chen and Li, 1995) are also expected to play an important role in lifting up the atmospheric pollutants vertically. The atmospheric pollutants then remain aloft as aerosol to participate in cloud formation. Hence, the cloud microphysics is determined from the concentration and various modes of aerosol.

Figure 6 depicts the scatterplot of CG lightning flash rate with AOD. It is seen from the plot that a positive linear correlation exits between AOD and CG lightning flash rate. Such linear correlation is not unexpected, rather consistent with the physical laws. A high value of lightning flash rate means the amount of charge destroyed per unit area per unit time is very high. In an opaque atmosphere, where aerosol optical depth is higher, such charge destruction process happens faster than usual. Increased aerosol loading in cloud mixed phase region leads to an accelerated charge destruction process which in turn enhances the rate of lightning flash (Yuan et al., 2011). It is assumed that larger amount of particulate matter from the surface is expected to be migrated in clouds with low vertical extent to create excess CG lightning flash count.

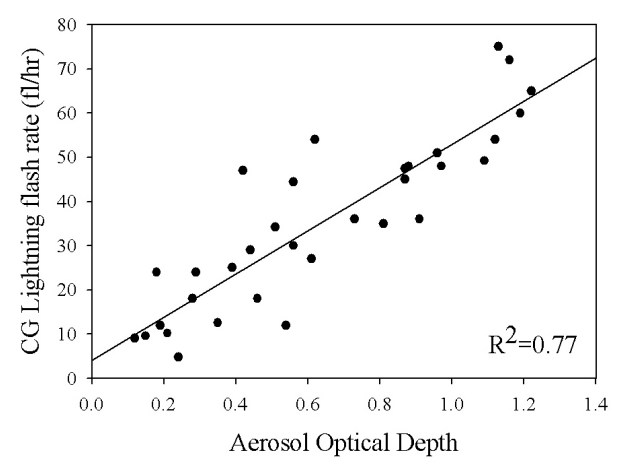

Figure 6. Scatterplot of CG lightning flash count with aerosol optical depth (AOD).

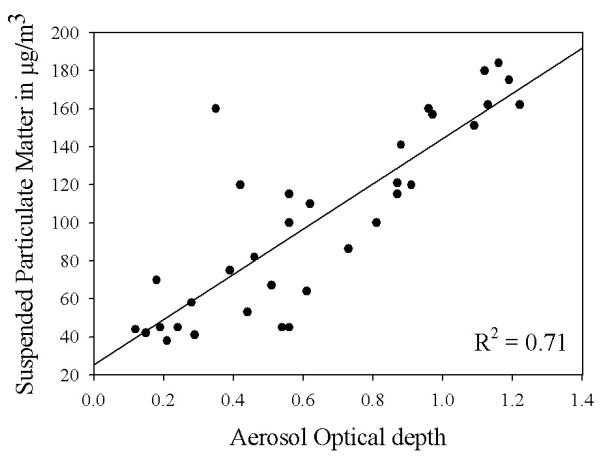

Figure 7. Scatterplot of ground-based SPM measurement and satellite-based AOD measurements.

Figure 7 represents a scatterplot of ground-based SPM measurement and satellite-based AOD measurements. High positive correlation is found between the plotted parameters over Taipei during the premonsoon season. During the premonsoon season, an innumerable amount of particulate matter from the surface goes aloft with thunderstorm updraft and participate in cloud microphysical processes (Rogers and Yau, 1989). This particulate matter is expected to be infused into a thundercloud and serve as $\mathrm{CCN}$. As a result, the cloud opacity is changed and this change in cloud opacity is reflected in the AOD measurements. Anthropogenic particulate impurities in cloud water can affect the charge separation in the urban thundercloud appreciably by increasing the negative lightning activity (Steiger et al., 2002; Steiger and Orville, 2003). Higher concentration level of near-surface pollutant parameters can thus influence the CG lightning activity and flash rate. The higher number of pollutant-induced lightning flashes may then in turn influence greatly the surface $\mathrm{NO}_{\mathrm{x}}$ production over Taipei. In later atmospheric stage this nitrogen oxide gas $\left(\mathrm{NO}_{\mathrm{x}}\right)$ interacts with other trace gases in the atmosphere in the presence of sunlight and produces atmospheric ozone $\left(\mathrm{O}_{3}\right)$. The chemical reaction responsible for the creation of tropospheric ozone can be written as

$\mathrm{NO}_{2}+$ sunlight $\rightarrow \mathrm{NO}+\mathrm{O}$ 


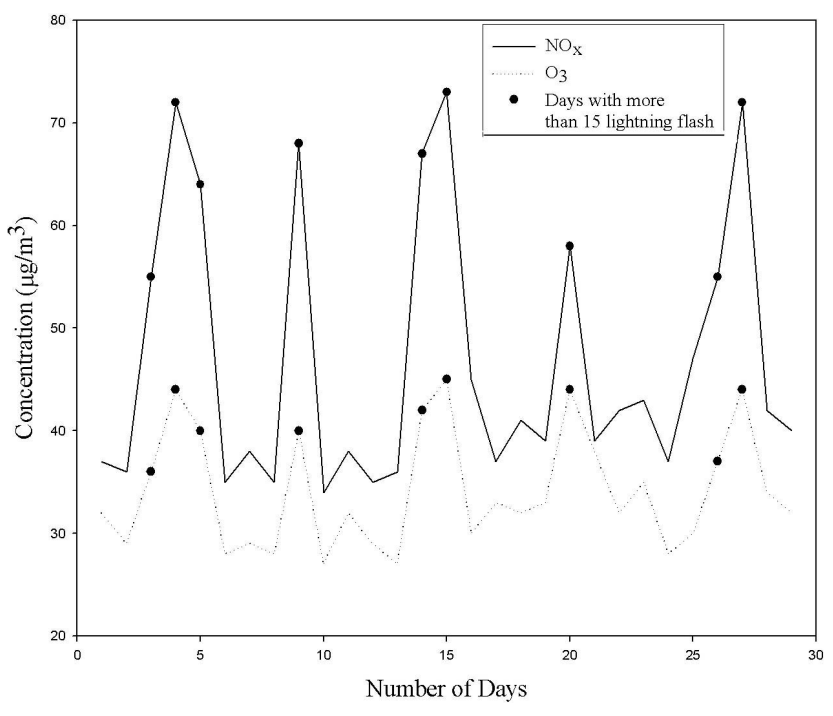

Figure 8. The variation of the daily average concentration of $\mathrm{NO}_{\mathrm{x}}$ and $\mathrm{O}_{3}$ with lightning days (number of lightning flashes $>15$ ) and non-lightning days.

$\mathrm{O}+\mathrm{O}_{2} \rightarrow \mathrm{O}_{3}$.

From the premonsoon CG lightning data we select few days with a considerable number of lightning flashes (>15) along with no lightning activity days. Then, the values are compared to the daily average concentration of $\mathrm{NO}_{\mathrm{x}}$ and $\mathrm{O}_{3}$ concentrations and are plotted in Fig. 8. Figure 8 reveals that the days with lightning flashes (>15) are associated with higher daily average values of $\mathrm{NO}_{x}$ and $\mathrm{O}_{3}$ compared to the days with no lightning flash. Close examination of the results suggests that the $\mathrm{NO}_{\mathrm{x}}$ concentration on days with lightning activity is more than 2-fold compared to the non-lightning days while the $\mathrm{O}_{3}$ concentration is increased approximately by 1.5 -fold. Such increase in $\mathrm{NO}_{\mathrm{x}}$ and $\mathrm{O}_{3}$ concentration on days with lightning strongly supports the transport phenomena of $\mathrm{NO}_{\mathrm{x}}$ and $\mathrm{O}_{3}$ from the upper or middle troposphere to the lower troposphere by downdraft of the thunderstorm during its dissipation stage. It is worth mentioning in this context that only a few studies about lower surface variation of ozone and $\mathrm{NO}_{\mathrm{x}}$ associated with thunderstorms are found in the literature (Ott et al., 2010; Minschwaner et al., 2008; Middey and Chaudhuri, 2013). Minschwaner et al. (2008), after conducting a study in central New Mexico, indicated a large enhancement in ozone (50\% above the mean) between about 3 and $10 \mathrm{~km}$ altitude within an electrically active storm and inferred that the observed ozone enhancements could have resulted from a number of possible processes, including the advection of polluted air from the urban environments, photochemical production by lightning-generated $\mathrm{NO}_{\mathrm{x}}$ from aged thunderstorm outflow, downward mixing of stratospheric air, or local production from within the thunderstorm. Several

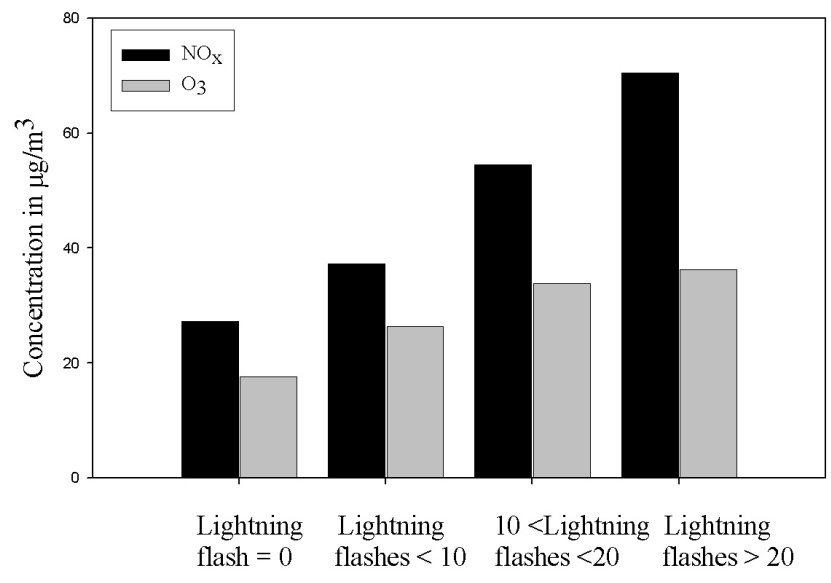

Figure 9. Variation of daily average concentrations of $\mathrm{NO}_{\mathrm{x}}$ and $\mathrm{O}_{3}$ with four categories of lightning days during premonsoon seasons.

studies have shown that the impacts of $\mathrm{NO}_{\mathrm{x}}$ on ozone are complex and nonlinear (Lin et al., 1988). Recent observation also indicates that the lightning-induced $\mathrm{NO}_{\mathrm{x}}$ production inside a thunderstorm has significant effect on surface ozone concentrations in the tropics (Pawar et al., 2012b).

Six years of CG lightning flash data are grouped into four categories during the premonsoon months. The four categories are days with no lightning flash, days fewer than 10 lightning flashes, days having 10 lightning flash per day to 20 lightning flashes per day, and days with more than 20 lightning flashes per day during premonsoon months of 20052010. These four categories of days are then plotted with daily average concentrations of $\mathrm{NO}_{\mathrm{x}}$ and $\mathrm{O}_{3}$ in Fig. 9. The variations of daily average concentrations of $\mathrm{NO}_{\mathrm{x}}$ and $\mathrm{O}_{3}$ with four categorically different days are prominently visible. $\mathrm{NO}_{\mathrm{x}}$ and $\mathrm{O}_{3}$ concentrations both are found to be increased from the days with no lightning flash to the days with lightning flashes more than 20 per day. The daily average values of $\mathrm{NO}_{\mathrm{x}}$ and $\mathrm{O}_{3}$ concentrations are varied from 27.27 to $76.43 \mu \mathrm{g} \mathrm{m}^{-3}$ for $\mathrm{NO}_{\mathrm{x}}$ and from 17.56 to $36.28 \mu \mathrm{g} \mathrm{m}^{-3}$ for $\mathrm{O}_{3}$.

\section{Conclusions}

The present research shows the relationship between CG lightning activity and surface pollutants over a tropical station Taipei during premonsoon seasons. Output of this study indicates that surface pollutants have a close association with CG lighting activity. This study also supports that highfrequency weather phenomena like lightning activity are not only influenced by meteorological parameters but also influenced significantly by tropospheric particulate matters. The present study strongly indicates that the SPM concentration at surface level affects the lightning flash rate during premonsoon season over Taipei which strongly corroborate the findings of Steiger et al. (2002) and Steiger and 
Orville (2003), who have shown after conducting a long-term study that the CG flash density is affected by the urban area of Houston and southern Louisiana. Higher SPM concentration $\left(>160 \mu \mathrm{g} \mathrm{m}^{-3}\right.$ ) corresponds to higher lightning flash rate irrespective of the cloud base formation: either it is nearer to the surface or at higher level. Near-surface SPM and PM $_{10}$ contribute significantly to increase AOD and hence serve as $\mathrm{CCN}$ and influence lightning activity. These results strongly support that pollution plays a key role in lightning enhancement (Steiger and Orville, 2003; Naccarato et al., 2003; Soriano and Pablo, 2002; Kar et al., 2009). Additional investigation suggests that the $\mathrm{NO}_{\mathrm{x}}$ concentration on days with lightning activity is more than 2-fold compared to the nonlightning days while the $\mathrm{O}_{3}$ concentration is increased 1-fold during premonsoon lightning activity. Such increase in $\mathrm{NO}_{\mathrm{x}}$ and $\mathrm{O}_{3}$ concentration on days with lightning strongly supports the transport phenomena of $\mathrm{NO}_{\mathrm{x}}$ and $\mathrm{O}_{3}$ from the upper or middle troposphere to the lower troposphere by downdraft of the thunderstorm during its dissipation stage. It is supposed that the increased lightning activity can enhance the $\mathrm{NO}_{x}$ production which in turn can enhance the surface $\mathrm{O}_{3}$ formation through photochemical reaction in the presence of sunlight as is evident from the present study. A higher concentration level of $65 \mu \mathrm{g} \mathrm{m}^{-3}$ is found for $\mathrm{NO}_{\mathrm{x}}$ during premonsoon lightning activity. Surface ozone is also found to be at higher concentration levels during significant lightning activity days, and it follows a similar pattern with total number of lightning flashes over the years. Overall, studies suggest that enhanced surface pollution in a near-storm environment is strongly related to the increased lightning activity, which in turn increases the surface $\mathrm{NO}_{\mathrm{x}}$ level and surface $\mathrm{O}_{3}$ concentration over the area under study.

Acknowledgements. Financial support of the National Science Council (NSC) of Taiwan through grant no. NSC 102-2221-E-008034 101-2221-E-008-019, NSC 101-2111-M-008-018 and NSC 102-2111-M-008-027 is sincerely acknowledged. Thanks are given to Tai Power Company of Taiwan for providing us the lightning data. We are also extremely grateful to the anonymous reviewers for their valuable critical comments which helped us a lot to improve the standard of the manuscript.

Topical Editor K. Hosokawa thanks two anonymous referees for their help in evaluating this paper.

\section{References}

Bond, D. W., Steigera, S., Zhang, R., Tie, X., and Orville, R. E.: The importance of $\mathrm{NO}_{\mathrm{x}}$ production by lightning in the tropics, Atmos. Environ., 36, 1509-1519, 2002.

Bréon, F. M., Tanré, D., and Generoso, S.: Aerosol effect on cloud droplet size monitored from satellite, Science, 295, 834-838, 2002.

Chameides, W. L. and Walker, J. C. G.: A photochemical theory of tropospheric ozone, J. Geophys. Res., 78, 8751-8760, 1973.
Chang, C. T., Tsai, C. J., Lee, C. T., Chang, S. Y., Cheng, M. T., and Chein, H. M.: Difference in $\mathrm{PM}_{10}$ concentration measured by $\beta$ gauge monitor and hi-vol sampler, Atmos. Environ., 35, 57415748, 2001.

Chaudhuri, S. and Middey, A.: Nowcasting thunderstorms with graph spectral distance and entropy estimation, Meteorol. Appl., 18, 238-249, 2011.

Chen, C. S. and Chen, Y. L.: The rainfall characteristics of Taiwan, Mon. Weather Rev., 131, 1323-1341, 2003.

Chen, Y. L. and Li, J.: Characteristic of surface airflow and pressure patterns over the island of Taiwan during TAMEX, Mon. Weather Rev., 123, 695-716, 1995.

Choi, Y., Wang, Y., Zeng, T., Martin, R. V., Kurosu, T. P., and Chance, K.: Evidence of lightning $\mathrm{NO}_{\mathrm{x}}$ and convective transport of pollutants in satellite observations over North America, Geophys. Res. Lett., 32, L02805, doi:10.1029/2004GL021436, 2005.

Crutzen, P. J.: A discussion of the chemistry of some minor constituents in the stratosphere and troposphere, Pure. Appl. Geophys., 106, 1385-1399, 1973.

Farias, W. R. G., Pinto Jr., O., Naccarato, K. P., and Pinto, I. R. C. A.: Anomalous lightning activity over the Metropolitan Region of São Paulo due to urban effects, Atmos. Res., 91, 485-490, 2009.

Farias, W. R. G., Pinto Jr., O., Pinto, I. R. C. A., and Naccarato, K. P.: The influence of urban effect on lightning activity: Evidence of weekly cycle, Atmos. Res., 135-136, 370-373, 2014.

Hobbs, P. V., Harrison, H., and Robinson, E.: Atmospheric effects of pollutants: pollutants which affect clouds are most likely to produce modifications in weather and climate, Science, 183, 909915, 1974.

Kar, S. K., Liou, Y. A., and Ha, K. J.: Aerosol effects on the enhancement of cloud-to-ground lightning over major urban areas of South Korea, Atmos. Res., 92, 80-87, 2009.

Khain, A., Rosenfeld, D., and Pokrovsky, A.: Aerosol impact on the dynamics and microphysics of deep convective clouds, Q. J. Roy. Meteorol. Soc., 131, 2639-2663, 2005.

Lal, D. M. and Pawar, S. D.: Relationship between rainfall andlightning over central Indian region in monsoon and premonsoon seasons, Atmos. Res., 92, 402-410, 2009.

Lal, D. M. and Pawar, S. D.: Effect of urbanization on lightning over four metropolitan cities of India, Atmos. Environ., 45, 191-196, 2011.

Li, J., Chen, Y. L., and Lee, W. C.: Analysis of a heavy rainfall event during TAMEX, Mon. Weather Rev., 125, 1060-1081, 1997.

Li, Z., Niu, F., Fan, J., Liu, Y., Rosenfeld, D., and Ding, Y.: Longterm impacts of aerosols on the vertical development of clouds and precipitation, Nat. Geosci., 4, 888-894, 2011.

Lin, X., Trainer, M., and Liu, S. C.: On the nonlinearity of the tropospheric ozone production, J. Geophys. Res., 93, 15879-15888, 1988.

Liou, Y. A. and Kar, S. K.: Study of cloud-to-ground lightning and precipitation and their seasonal and geographical characteristics over Taiwan, Atmos. Res., 95, 115-122, 2010.

Lyons, W. A., Nemson, T. E., Williams, E. R., Cramer, J. A., and Turner, T. R.: Enhanced positive cloud-to-ground lightning in thunderstorms ingesting smoke from fires, Science, 282, 77-80, 1998. 
Martin, R. V., Sioris, C. E., Chance, K., Ryerson, T. B., Bertram, T. H., Wooldridge, P. J., Cohen, R. C., Neuman, J. A., Swanson, A., and Flocke, F. M.: Evaluation of space-based constraints on global nitrogen oxide emissions with regional aircraft measurements over and downwind of eastern North America, J. Geophys. Res., 111, D15308, doi:10.1029/2005JD006680, 2006.

Middey, A. and Chaudhuri, S.: The reciprocal relation between lightning and pollution and their impact over Kolkata, India, Environ. Sci. Pollut. R., 20, 3133-3139, 2013.

Minschwaner, K., Kalnajs, L. E., Dubey, M. K., Avallone, L. M., Sawaengphokai, P. C., Edens, H. E., and Winn, W. P.: Observation of enhanced ozone in an electrically active storm over Socorro, NM: Implications for ozone production from corona discharges, J. Geophys. Res., 113, D17208, doi:10.1029/2007JD009500, 2008.

Naccarato, K. P., Pinto Jr., O., and Pinto, I. R. C. A.: Evidence of thermal and aerosol effects on the cloud-to-ground lightning density and polarity over large urban areas of Southeastern Brazil, J. Geophys. Res., 30, 1674-1677, 2003.

Noxon, J. F.: Atmospheric nitrogen fixation by lightning, Geophys. Res. Lett., 3, 463-465, 1976.

Orville, R. R., Huffines, G., Gammon, J. N., Zhang, R., Ely, B., Steiger, S., Phillips, S., Allen, S., and Read, W.: Enhancement of cloud-to-ground lightning over Houston, Texas, Geophys. Res. Lett., 28, 2597-2600, 2001.

Ott, L. E., Pickering, K. E., Stenchikov, G. L., Allen, D. J., DeCaria, A. J., Ridley, B., Lin, R. F., Lang, S., and Tao, W.: Production of lightning $\mathrm{NO}_{\mathrm{x}}$ and its vertical distribution calculated from threedimensional cloud-scale chemical transport model simulations, J. Geophys. Res., 115, D04301, doi:10.1029/2009JD011880, 2010.

Pawar, S. D., Lal, D. M., and Murugavel, P.: Lightning characteristics over central India during Indian summer monsoon, Atmos. Res., 106, 44-49, 2012a.

Pawar, V., Pawar, S. D., Beig, G., and Sahu, S. K.: Effect of lightning activity on surface $\mathrm{NO}_{\mathrm{x}}$ and $\mathrm{O}_{3}$ over a tropical station during premonsoon and monsoon seasons, J. Geophys. Res., 117, D05310, doi:10.1029/2011JD016930, 2012b.

Petersen, W. A. and Rutledge, S. A.: On the relationship between cloud-to-ground lightning and convective rainfall, J. Geophys. Res., 103, 14025-14040, 1998.

Pinto, I. R. C. A., Pinto Jr., O., Gomes, M. A. S. S., and Ferreira, N. J.: Urban effect on the characteristics of cloud-to-ground lightning over Belo Horizonte-Brazil, Ann. Geophys., 22, 697-700, doi:10.5194/angeo-22-697-2004, 2004.

Qie, X., Yuan, T., Xie, Y., and Ma, Y. M.: Spatial and temporal distribution of lightning activities on the Tibetan plateau, Chinese J. Geophys., 47, 1122-1127, 2004.

Richard, P.: Auffray G: VHF-UHF interferometric measurements, applications to lightning discharge mapping, Radio Sci., 20, 171$192,1985$.
Richard, P., Delannoy, A., Labaune, G., and Laroche, P.: Results of spatial and temporal characterization of the VHF-UHF radiation of lightning, J. Geophys. Res., 91, 1248-1260, 1986.

Rogers, R. R. and Yau, M. K.: A short course in cloud physics, 3rd Edn., Pergamon Press Oxford, 1989.

Seinfeld, J. H. and Pandis, S. N.: Thermodynamics of Aerosols, in Atmospheric Chemistry and Physics, Wiley, New York, 1998.

Seinfeld, J. M.: Air Pollution: Physical and Chemical Fundamentals, McGraw-Hill Co New York, 1975.

Soriano, L. R. and Pablo, F.: Effect of small urban areas in central Spain on the enhancement of cloud-to-ground lightning activity, Atmos. Environ., 36, 2809-2816, 2002.

Steiger, S. M. and Orville, R. E.: Cloud-to-ground lightning enhancement over Southern Louisiana, Geophys. Res. Letts., 30, 1975, doi:10.1029/2003GL017923, 2003.

Steiger, S. M., Orville, R. E., and Huffines, G.: Cloud-to-ground lightning characteristics over Houston, Texas: 1989-2000, J. Geophys. Res., 107, 4117, doi:10.1029/2001JD001142, 2002.

Tie, X., Madronich, S., Walters, S., Zhang, R., Rasch, P., and Collins, W.: Effect of clouds on photolysis and oxidants in the troposphere, J. Geophys. Res., 108, 4642, doi:10.1029/2003JD003659, 2003.

Trenberth, K. E., Miller, K., Mearns, L., and Rhodes, S.: Effects of changing climate on weather and human activities, University Science Books Sausalito, 2000.

Wang, Y., Wan, Q., Meng, W., Liao, F., Tan, H., and Zhang, R.: Long-term impacts of aerosols on precipitation and lightning over the Pearl River Delta megacity area in China, Atmos. Chem. Phys., 11, 12421-12436, doi:10.5194/acp-11-12421-2011, 2011.

Westcott, N. E.: Summertime cloud-to-ground lightning activity around major Midwestern urban areas, J. Appl Meteorol., 34, 1633-1642, 1995.

Williams, E. R., Mushtak, V., Rosenfeld, D., Goodman, S., and Boccippio, D.; Thermodynamic conditions favorable to superlative thunderstorm updraft, mixed phase microphysics and lightning flash rate, Atmos. Res., 76, 288-306, 2005.

Yeh, H. C. and Chen, Y. L.: The role of offshore convergence on coastal rainfall during TAMEX IOP 3, Mon. Weather Rev., 130, 2709-2730, 2002.

Yuan, T. and Qie, X.: Study on lightning activity and precipitation characteristics before and after the onset of the South China Sea summer monsoon, J. Geophys. Res., 113, D14101, doi:10.1029/2007JD009382, 2008.

Yuan, T., Remer, L. A., Pickering, K. E., and Yu, H.: Observational evidence of aerosol enhancement of lightning activity and convective invigoration, Geophys. Res. Lett., 38, L04701, doi:10.1029/2010GL046052, 2011.

Zhoua, Y., Soulab, S., Pontb, V., and Qiea, X.: $\mathrm{NO}_{\mathrm{X}}$ ground concentration at a station at high altitude in relation to cloud-to-ground lightning flashes, Atmos. Res., 75, 47-69, 2005. 